\title{
DA CHEGADA DO FENÔMENO ESQUIZOFÔNICO À AURORA DO MEIO TÉCNICO-CIENTÍFICO INFORMACIONAL (1890-1965): A MÚSICA DO RECIFE NO TEMPO E NO ESPAÇO
}

\author{
FROM THE ARRIVAL OF SCHIZOPHONIA TO THE DAWN OF THE \\ TECHNICAL-SCIENTIFIC-INFORMATIONAL ENVIRONMENT (1890- \\ 1965): THE MUSIC OF RECIFE IN TIME AND SPACE. \\ DÈS L'ARRIVÉE DE SCHIZOPHONIE À L'AUBE DU MILLIEU \\ TECHNIQUE-SCIENTIFIQUE-INFORMATIONNEL (1890-1965): LA \\ MUSIQUE DU RECIFE DANS LE TEMPS ET L'ESPACE
}

\section{Cristiano Nunes Alves}

Doutor em Geografia pela Universidade Estadual de Campinas (Unicamp).

Rua Ângela Signori Grigol, 430, Jardim América, Barão Geraldo. Campinas. CEP 13084-405. Telefone (+55 19) 3473-1963

cris7cris7@yahoo.com.br

\section{RESUMO}

Problematizando a circulação da variável informacional no território, objetivamos avaliar os nexos entre a dinâmica urbana e a produção musical no Recife no período de 1890 a 1965. Por meio da noção de Circuito Sonoro - o conjunto de materialidades e ações movimentado em torno das variáveis música e som - analisamos a capital pernambucana desde a chegada da esquizofônia - a cisão entre procedência e difusão sonora - até a aurora do meio técnico-científico informacional em meados dos anos 1960. O presente texto resultou de levantamento bibliográfico e documental, bem como se pautou na reunião de informações primárias a partir de visitas técnicas e entrevistas semiestruturadas realizadas junto a agentes ligados à temática. Observa-se a dialética existente entre as sucessivas reorganizações do meio ambiente construído, seus fluxos e ideias, e o adensamento da produção musical e fonográfica no Recife. Trata-se de uma contribuição às discussões sobre as possibilidades de pensar e efetivar usos do território menos desiguais na cidade contemporânea.

PALAVRAS-CHAVE: Uso do território, Periodização, Recife, Música, Produção Fonográfica.

\section{ABSTRACT}

The aim is to evaluate the relationship between urban dynamics and music production in Recife between 1890 and 1965 by analyzing the circulation of the informational variable within the territory. By means of the Sound Circuit concept - the set of materiality and 
actions which revolve around the music and sound variables - we investigate the capital of Pernambuco from the moment of the arrival of schizophonia - when a recorded sound is split off from its original source, causing a dislocation between what you see and what you hear - to the dawn of the technical-scientific informational environment in the mid-1960s. This paper was based upon bibliographic and documentary surveys and also upon the compilation of primary information collected during technical visits and semi-structured interviews with agents associated with this theme. Notice the existing dialectic between the successive reorganization of the environment, its flows and ideas, and the density of the music and phonographic production in Recife. This study is a contribution to the discussions about the possibilities of thinking and carrying less unequal uses of the territory in the contemporary city.

KEY-WORDS: Use of the territory, Periodization, Recife, Music, Phonographic Production.

\section{RÉSUMÉ}

En considerant la variable informationnelle sur le territoire, on cherche à évaluer les liens entre la dynamique urbaine et la production musicale à Recife dans la période du 1890 à 1965. À partir du concept de Circuit de Son - le conjoint des matérialités et des actions dinamisées autour des variables musique et son - on analyse la capitale de létat de Pernambuco depuis l'arrivée de schizophonie - la scission entre l'origine et la diffusion sonore - jusquà l'aube du moyen technique-scientifique informationnel au milieu des années 1960. Larticle est basé sur une enquête bibliographique et documentaire autant que dans la réunion d'informations primaires à partir de visites techniques et d'entretiens semi-structurés avec les agents liés au thème. On remarque la dialectique existant entre les réorganisations successives de l'environnement bâti, ses flux et ses idées et la densité musicale et phonographique à Recife. Finalement Il s'agit d'une contribution aux discussions sur les possibilités de penser et d'effectuer des usages du territoire moins inégalitaires dans la ville contemporaine.

MOTS-CLÉ: Usage du territoire, Periodisation, Recife, Musique, Production Phonographique 


\section{INTRODUÇÃO}

A cidade do Recife, atualmente o abrigo de 1.599.514 habitantes (Instituto Brasileiro de Geografia e Estatística, IBGE, Estimativa 2013), tem uma história marcada pela desigualdade socioterritorial e pela riqueza cultural, largamente expressa pela sua produção musical.

Problematizando a circulação da variável informacional no território, objetivamos no presente artigo, avaliar os nexos entre a dinâmica urbana e a produção musical no Recife no período entre 1890 e 1965. Centramos nossa análise sobre a capital pernambucana no período desde o final do século XIX, e a chegada da esquizofônia (SCHAFER, 1997 [1977], p. 133), a cisão entre procedência e difusão sonora engendrada a partir da criação do telégrafo, afastando os sons de seus contextos originais por meio da "transmissão ou reprodução eletroacústica”, até meados dos anos 1960 e a aurora do meio-técnico-científico informacional (SANTOS, 1997). Ou seja, lançamos o olhar para um período caracterizado pelo grande aumento da difusão da informação sonora (incluindo a circulação da produção musical) possibilitado pelo fenômeno esquizofônico que culmina com a constituição de um meio no qual a variável informacional se torna o elemento crucial da dinâmica do sistema mundo (DOLLFUS, 1993).

Trata-se da análise do ínterim no qual a informação sonora e musical passa a circular sem necessariamente depender do corpo humano, aspecto que pode trazer interessantes elementos para refletir sobre a natureza dos fluxos imateriais na urbe de ontem e de hoje.

Propomos analisar o modo como a cidade produz e é produzida pelo espaço geográfico, a hibridização entre sistemas de objetos e sistemas de ações (SANTOS, 1997) operacionalizando a noção de Circuito Sonoro.

Responsável por importantes espessuras, entendemos a presença do Circuito Sonoro e de sua constituição a partir de uma série de elementos. A dinâmica do Circuito recifense implica no uso das ruas, praças, dos objetos e sistemas técnicos de informação desde receptores de rádio até amplificadores de som - estúdios fonográficos, emissoras de rádio, lojas de discos, entre outros. Sua dinâmica engloba o registro material da produção fonográfica, as mediações cotidianas das experiências relacionadas à música: associações e conflitos seja na produção do registro sonoro nos eventos musicais nas ações de trabalhadores culturais ou nos fluxos informacionais embutidos nos lugares.

Com o alvitre de esmiuçar a música e o movimento do território a partir da noção de Circuito Sonoro visamos melhor compreender a situação concreta resultante do processo de interação de materialidades e espacialização de normas e ações que a partir dos usos 
mediados pela técnica configuram o espaço geográfico e os seus lugares no Recife. Queremos assim, entender como funcionam as variáveis em torno da produção musical e fonográfica e quais são as suas repercussões espaciais.

O presente texto baseou-se em levantamento bibliográfico e documental sobre a temática reunindo-se informações presentes em livros, artigos de periódicos, artigos de jornais, mapas, fotos, entre outros. No desenvolvimento dessa metodologia além da consulta a arquivos digitais esmiuçaram-se os arquivos de bibliotecas, fundações, universidades e órgãos do poder público no Recife e fora dele. Fora essencial ainda a reunião de informações primárias a partir de visitas técnicas a locais conformados e apropriados pelo Circuito Sonoro recifense e entrevistas semiestruturadas realizadas junto a agentes ligados à temática - tais quais músicos, produtores musicais, locutores de rádios, jornalistas, entre outros. As informações primárias se encontram no texto acompanhadas de um asterisco.

O presente artigo divide-se do seguinte modo: após essa breve introdução problematizamos o tema destacando o recurso à periodização, instrumental teórico caro ao exame dos processos formadores do espaço geográfico por meio do enfoque genético (ISNARD, 1982). Em seguida, examinamos a situação em torno do Circuito Sonoro abrigado na urbe recifense. Oferecemos ao leitor uma periodização para a música e a cidade do Recife desde a chegada da esquizofonia até o esboço do meio técnico-científico informacional cindida pelos anos 1940, momento decisivo para a urbanização brasileira, entre outros por conta do aprofundamento do fato urbano e instalação da indústria cultural no país.

Focamos nossa imaginação geográfica (SOJA, 2008) na tarefa de abrir os ouvidos para o que o território e seus agentes têm a dizer, partido de método condutor em meio às trilhas da música e dos sons na urbe recifense. Ora, assim como a música, o território tem seus ritmos, pulsos, cores, texturas e timbres; aspectos que nem mesmo os processos espaciais conseguem calar.

\section{EXPONDO O MÉTODO DE PESQUISA: A MÚSICA, 0 TERRITÓRIO USADO E 0 RECURSO A PERIODIZAÇÃO}

No exame da música e do uso do território recifense ao longo do tempo, lançamos mão do recurso à periodização (SANTOS, 1997). Entender o funcionamento do Circuito Sonoro nos remete às continuidades e descontinuidades territorializadas, um "tempo empiricizado" (SANTOS, 1997), manifesto nos sistemas de eventos nos lugares, motor e amarração dos hábitos cotidianos. 
Monbeig (1984 [1950]) evoca o ouvido do geógrafo fazendo vir à tona por meio dos sons, as regiões do interior de São Paulo em meados dos anos 1870, sendo então, paulatinamente "conquistadas pelo homem." Ao mesclar a geografia e a audição, Monbeig (1984 [1950], p. 22) inspira-nos na tarefa de vertemos a nossa percepção e reflexão a um só tempo para a música e para o espaço geográfico:

Mesmo que fechasse os olhos à paisagem, o viajante não escaparia à impressão de nova zona: seus companheiros se comprazem em citar cifras prestigiosas, que testemunharam o surto das cidades atravessadas, a evocar o heroico nascimento delas, ou a narrar os bons negócios que nelas se fizeram (...) Ouvia-se falar português, mas com o zetacismo do japonês ou o sotaque do alemão. Os corredores dos trens ficam abarrotados.

Igualmente instrumental a meditação sobre o espaço geográfico e o componente sonoro, lançamos mão de Schafer (1997, p. 185) e a noção de paisagem sonora, designando "um campo de interações" criado pela simultaneidade e o intercâmbio de eventos sonoros situados nos lugares ${ }^{1}$.

Nossa reflexão parte da categoria território usado (SANTOS, 1997), sinônimo de espaço geográfico, entretanto apontando para "a necessidade de um esforço destinado a analisar sistematicamente a constituição do território.” (SANTOS \& SILVEIRA, 2001, p. 20). Malgrado o poder desigual de cada um de seus agentes, o território usado "um quadro de vida" (SILVEIRA, 2011, p. 35), abriga a todos e guarda a marca de seu tempo.

Ponderação importante para a análise do território usado, Castro (1953) afirma ser o organismo urbano o traço que melhor reflete e define a ação do homem, criando a geografia dos lugares, símbolo da imposição do cultural sobre o natural.

A cidade, concepção precedente à ideia de urbano (LENCIONI, 2008) seria o centro nodal do desenvolvimento dos sistemas de circulação material e imaterial, tornando-se "o ponto de referência de uma gama de conexões que recobre e vai deitar-se sobre o espaço terrestre como um todo numa única rede" (MOREIRA, 2007, p. 58). Tratar-se-iam as cidades de "produtoras do espaço geográfico" por excelência estendendo o seu poder a um espaço circundante (ISNARD, 1978, p. 12).

Para pensar a circulação de informações no espaço urbano, lembramos Pred (1979, p. 13) ao asseverar que as cidades se articulam em um sistema social complexo, de caráter regional ou nacional, o sistema de cidades, caracterizado pela "tendenciosidade espacial na disponibilidade de informações", formando um dinâmico "campo de informação". Nessa ponderação, o autor supracitado procura sublinhar a importância do controle dos

Ainda sobre o tema da paisagem sonora, consultar Martignoni (2006) 
fluxos informacionais, como meios difusores da reorganização do conjunto de cidades, implicando que a mudança em um lugar reverbere alhures.

A esse respeito, lembra Santos (1994 a, p. 115), devemos ter "consciência da época em que vivemos" marcada pelo crescente papel da informação, tornada força motriz da dinâmica socioespacial, a "variável chave" configurando o meio técnico-científico informacional.

Com a periodização, buscamos as camadas do projeto social acumuladas nos lugares. Conforme Silveira (1999, p. 22), as demarcações dos períodos evidenciam "situações geográficas" decorrência de um "conjunto de eventos geografizados", pois tornados "materialidade e norma" mudando os lugares e a sua geografia. Por seu turno, Ribeiro (1994) e Connerton (1999), afirmam a necessidade de considerar a memória dos lugares, enquanto, na defesa de uma análise geomusical ao longo do tempo, Gironcourt (1927, p. 302) propõe a escuta "da grande voz dos ancestrais que ressoa desde a pré-história."

Nesse sentido, ensina-nos Hartshorne (1978) que em muitos casos os processos correntes não têm capacidade explicativa, o que obriga o geógrafo a voltar mais um pouco no tempo a fim de captar o encadeamento da geografia dos lugares em diferentes momentos:

Os geógrafos estudam o passado não só como 'a chave do presente', mas também em função do seu próprio conteúdo geográfico. Cada período passado possuiu sua geografia 'presente', e o estudo comparativo das diferentes geografias através de sucessivos períodos de tempo oferece um quadro da geografia em mudança, de uma determinada área. Desse modo, a dimensão histórica do tempo se combina às dimensões do espaço.

(HARTSHORNE, 1978, p. 90)

Recurso instrumental a uma decomposição analítica do componente temporal do espaço, Arroyo (1996, p. 79) sugere que passado, presente e futuro são simultaneamente unos e diferenciáveis: "Assim como o passado é um componente do presente e só pode ser explicado por ele, o presente contém elementos de um futuro não realizado, e é apenas a partir dele que o futuro pode ser percebido." Nessa via se pronuncia Ribeiro (2012, p. 103), adicionando à temática o conflito inerente a dominação de escalas temporais como um dos elementos formadores do presente: "o futuro é mais do que a projeção do presente; na verdade, não precisa, não deve ser a projeção linear do presente. Ademais, o presente não é só o presente, o presente é uma mistura da presentificação brutal do mundo com os interesses neles dominantes."

Vê-se que o trabalho do geógrafo passa pela integração espacial de "tempos cuja duração e, consequentemente, cujo significado são diferentes” (DOLLFUS, 1973, p. 116).

“... la grande voix des ancêtres, qui résonne depuis la préhistoire” (GIRONCOURT, 1927, p. 302) 
Daí Isnard $(1978,1982)$ destacar a importância do enfoque genético para a análise espacial apresentando a noção de "composição poligênica" ao encontro do fato de que consecutivamente, as gerações conjugam-se a determinadas organizações espaciais, resultando em formas-conteúdo oriundas de diversas épocas coexistindo no espaço geográfico:

... a sociedade e o espaço evoluem segundo uma diacronia paralela. A cada geração humana corresponde uma geração espacial (...) uma organização do espaço desaparece lentamente enquanto outra vai tomando o seu lugar: esta é a razão pela qual, em dado momento da evolução, um espaço geográfico pode apresentar uma composição poligênica.

(ISNARD, 1978, p. 10)

Por fim, atentando para Correa (2000) e Silveira (2011) nosso enfoque genético sobre o Recife e a música pauta-se na unidade do fato urbano e da formação socioespacial, manifestação da história territorial: "Na análise da problemática urbana, parece primordial partir da indissociabilidade histórica da formação socioespacial - que diz respeito às maneiras como o território foi usado ao longo da história - das dinâmicas e formas urbanas" (SILVEIRA, 2011, p. 35). Nesse viés e acerca da injunção entre rede urbana e tempo, afirma Correa (2000, p. 122) que "O tempo, impregnado de processos, funções e formas, assim como das contradições delas derivadas, é um determinante fundamental que fixa ao menos temporariamente, os elementos combinados da rede urbana."

Municiados por tais premissas, apresentamos a seguir uma proposta de periodização para as variáveis "música" e "uso do território" no Recife, destacando a sucessão de situações geográficas conformadas na capital pernambucana desde a chegada do fenômeno esquizofônico até o momento em que ganharia corpo o meio-técnico-científico informacional.

\section{O RECIFE E A CHEGADA DO FENÔMENO ESQUIZOFÔNICO: OS SONS DA VIDA URBANA E INDUS- TRIAL (ANOS 1890-1930)}

A mancha urbana do Recife, no final do século XIX, compreendia os bairros Santo Antônio e São José (MELO, 1978). No último quartel do século XIX a população do Recife diminuíra, passando de 116 mil no ano de 1872 para 111 mil no ano de 1900. Todavia em virtude da abolição da escravatura no crepúsculo daquele século XIX um grande fluxo migratório de escravos libertos chegava ao Recife. Como o complexo rural adquiria distinta natureza social, ocorria a migração para a cidade ${ }^{3}$.

No que tange ao Circuito Sonoro, esse afluxo significou, entre outros, a chegada à capital de um "Grande número de músicos (...) compositores ou não, notadamente aque-

O aumento do número de migrantes dá-se em virtude do afluxo de pernambucanos do interior, que viriam a ser um quarto da população no ano de 1922, seguido do afluxo de pessoas de outros lugares da região nordeste (SINGER, 1968). 
les músicos de instrumentos de sopro", oriundos do interior de Pernambuco (SANGUINETT, 1984, p. 221).

Nos albores do século XX Recife figurava como cidade de considerável espessura informacional, "não era apenas um centro comercial e administrativo mas também um centro de educação, com numerosas escolas superiores e de ensino médio, de saúde e industrial", como assevera Andrade (1979, p. 96). Todavia, Singer (1968, p. 331) acusa que na época ocorrera a "frustração do movimento industrializador que empolga o Recife", implicação da "perda do mercado externo por parte dos principais produtos nordestinos açúcar e algodão - ao passo que as exportações do sustentáculo da economia do centro-sul - o café - se expandiam sem cessar" (IDEM).

Vertendo nosso olhar para a paisagem sonora (SCHAFER, 1997 [1977]) recifense do início do século XX, lançamos mão de Freyre (1942, p. 74) quando este nos conta que os sinos das igrejas eram "som para tudo avisar" e o africano era quem fazia bradar o sino bem como era "o músico das festas da igreja." Nessa via, entre os anos de 1904 e 1907, Eustógio Vanderley se tornou o primeiro pernambucano a ter suas composições registradas na pioneira série fonográfica brasileira da marca Odeon (PHAELANTE, 1998).

Antecessores do cinema em 1909 estabilizavam-se na Rua Nova os animatógrafos Royal e Vitória, ao passo que se difundiam pela Boa Vista os cineteatros onde ocorriam apresentações de piano e "pequenas orquestras" (SILVA, 1998, p. 8). Nessa época, assinala Nóbrega (2002, p. 80) e até meados do século XX difundiam-se na capital pernambucana, os pregões, tipo de comércio de rua baseado em anúncios na "forma de música, rimas e gritos que comerciantes faziam" para chamar atenção.

Igualmente sobre o Circuito Sonoro, é importante destacar o frevo, assim como "as corporações de ofícios, as companhias de negros e as irmandades religiosas" (MOTA, 2001: 91), uma síntese da expressão das massas trabalhadoras aglomeradas nas manifestações dos subalternos da cidade do Recife no início do século XX. Araújo (1996) propõe que o termo frevo veio designar a agitação das multidões nas ruas, pulando e dançando ao som das marchas carnavalescas. A massa em ebulição remetia à fervura, ao rebuliço, ao frevar; uma tendência cultural capaz de abordar a política de um modo carnavalesco, de um só golpe, com um olhar crítico e cômico.

Teles (2000) lembra que o termo frevo assim como o samba e o forró, designou inicialmente um situação e não um gênero musical ${ }^{4}$. O modo rude de ação que crescera sem controle e de maneira abrupta tomara de assalto as elites, resultado do convívio entre tra-

4 Sobre a origem e a evolução do frevo em termos musicais, consultar Maciel (2005). 
balhadores brancos ou negros recém-libertos e a "classe perigosa" dos vadios, das prostitutas ou dos capoeiras. O poder instalado optou nos primeiros anos do século XX pelo enquadramento sem confronto, cooptando os trabalhadores a partir de uma postura paternalista mediante ação intensa e sutil, não apenas durante os festejos de Momo, bem como ao longo do ano:

O Estado através da instância policial, tentou aproximar-se e ganhar confiança e simpatia do povo comum, atuando especialmente por ocasião do carnaval e junto aos clubes carnavalescos pedestres. A mudança de postura da polícia, em relação aos divertimentos populares do carnaval de rua - passando de repressora, violenta e arbitrária a guarnecedora dos préstitos dos clubes pedestres, a partir de 1904, era uma estratégia de ação política, visando à cooptação da classe trabalhadora, à disciplina da massa urbana e à criação de um novo padrão de convivência pública entre as classes sociais.

(ARAÚJO, 1996, p. 405).

Para entender a ebulição do contexto de espraiamento do frevo vale aludir que no início dos anos 1900 a questão da escassez do solo urbano já se impunha no Recife ${ }^{5}$, resultado do longo processo de concentração de terras, fator decisivo agravado pela condição de sítio recifense, entre o mar e os morros.

Também no começo do século XX, além do Plano de Saneamento criado por Saturnino Brito, ocorreu a reforma do Bairro do Recife e a reestruturação do Porto. Uma série de construções do período colonial foram derrubadas, dando lugar a projetos urbanos fortemente inspirados em Haussman ${ }^{6}$ e nos preceitos urbanísticos modernos. Retrato da paisagem sonora recifense de outrora, os sons que emanavam pelo bairro expunham aquela ocasião de destruição e reconstrução urbana sofrida pela capital pernambucana: "Avenidas planejadas, edifícios suntuosos, os imprevistos e a multiformidade da vida nova que iriam se instalar nesse cenário, eram aguardadas ansiosamente, em meio ao som das picaretas que deviam ser ouvidos em todos os cantos do bairro" (GOMES, 2006, p. 113).

No início dos anos 1920 a economia do Recife, lugar no qual residiam 238.843 mil pessoas, sofreu duro golpe, resultado da concorrência da economia paulista com a produção açucareira pernambucana ${ }^{7}$.

\footnotetext{
Vale refletir sobre a espessura da dinâmica urbana recifense no ano de 1900 a partir do trecho de Silva (1998, p. 7): “Surge o século XX com o Recife com a população de 113.106 habitantes. A cidade de então possuía 245 ruas, 29 praças, 215 travessas e 67 becos. Havia 17.147 prédios, dos quais 16.595 habitáveis; 169 em construção e 383 em ruínas, variando seus aluguéis entre 10 mil réis a 1 conto de réis (Informações extraídas pelo autor no guia: “O Recife, Capital do Estado de Pernambuco").

6 O Barão de Haussmann foi o responsável pela ampla reforma urbana em Paris (França) no final do século XIX durante a sua administração frente à prefeitura da cidade. Seus preceitos sobre urbanismo e planejamento, pautados, entre outros na higienização da urbe, demolição de construções antigas e abertura de avenidas, chegaram ao Brasil na época aportando ainda em São Paulo e no Rio de Janeiro.

7 O Governo Federal interviria determinando 10\% da produção para o nordeste. O mesmo não aconteceria com o algodão cuja produção praticamente acabou (FURTADO, 1974).
} 
O princípio desse período fora marcado pela difusão do meio esquizofônico e no ano de 1923, contexto de intensa disputa pela imposição de padrões na indústria fonográfica, a radiodifusão chegava oficialmente ao Brasil, no mesmo ano arribando no Recife.

Na cidade surgiram lojas de discos na Rua Nova, que abrigava do mesmo modo o Café Chic "ponto de confluência de estudantes e intelectuais, além de outros estabelecimentos na Rua da Imperatriz e Barão da Vitória” (AMORIM \& LOUREIRO, 2004, p. 79). Aumentaram a circulação das "victrolas" (SILVA, 1997) e se instalaram a Rádio Clube de Pernambuco (PRA 8), uma das primeiras, senão a primeira do país, ao lado das experiências radiofônicas realizadas no Rio de Janeiro-RJ e em Campinas-SP ${ }^{8}$.

Após um período operando experimentalmente em um estúdio improvisado na Ponte D’Uchoa, a Rádio Clube se instalou na Avenida Cruz Cabugá em Santo Amaro com um transmissor de 10 watts, suficiente para atingir todo o Recife. A emissora começou então a divulgação do frevo-canção, com letra, e do frevo-de-rua, um som instrumental, ambos vinculados a sua programação9. Ainda sobre o ambiente cultural daquele que seria o primeiro grande momento de difusão fonográfica via rádio, no ano de 1926 aconteceu o Congresso Regionalista de Recife. O ensejo marcou o lançamento do Manifesto Regionalista escrito por Gilberto Freyre, desdobramento de uma movimentação iniciada no início do século XX, em busca da conservação dos valores tradicionais, da defesa das raízes culturais frente ao modernismo e do desenvolvimento de uma percepção matricialmente nordestina (FONSECA, 1996).

Por outro lado, no Brasil durante a década de 1930, a inserção de mensagens comerciais e a disseminação de aparelhos receptores transformaram o rádio em um veículo de informação popular, caro, entre outros, à divulgação de bens e serviços culturais nas áreas urbanas:

A partir da década de 1930, com o surgimento e crescimento da venda de aparelhos valvulados, há um grande impulso rumo à popularização, começava a chamada Era do Rádio. O rádio tornara-se o grande instrumento provedor e divulgador do divertimento e do lazer urbano.

(SALDANHA \& CARRASCO, 2006, p. 158)

\footnotetext{
8 Mais informações consultar Alves (2010) e os relatos encontrados em um jornal de Campinas-SP a respeito das experiências radiofônicas do Padre Roberto Landell de Moura.

9 Vale destacar que, segundo Phaelante (1998) antes mesmo da "era do rádio", ao contrário do que propõem algumas análises, compositores pernambucanos se destacavam na tenra idade da produção fonográfica brasileira, seja nas composições de João Pernambuco, encarnadas por vários intérpretes, nas músicas do Maestro Abdon Lira interpretadas pela banda da Cada Edison, de Alfredo Gama na voz de Vicente Celestino ou nas músicas de Osvaldo Santiago sob a roupagem de Catulo da Paixão Cearense: "Antes do surgimento oficial do rádio no Brasil na década de 20, compositores pernambucanos já se destacavam na indústria do disco e alguns passaram a brilhar na história da música popular brasileira." (PHAELANTE, 1998, p. 42).
} 
Não por acaso, no período dos anos 1930 as músicas de diferentes lugares começaram a circular pelo país. Os músicos populares se inserem mais amplamente na divisão territorial do trabalho, surgindo os primeiros registros fonográficos.

No Recife, também em 1930, era fundado o Conservatório Pernambucano de Música, situado em Santo Amaro (SILVA, 1998). Na época ganhava corpo a produção artística dos que hoje são considerados figuras centrais do frevo, tais quais Capiba, Nélson Ferreira, Claudionor Germano, Irmãos Valença, Marambá, Maestro Zuzinha, entre outros ${ }^{10}$. A difusão desses artistas integrava uma relação simbiótica com a Rádio Clube, que, divulgando os nomes do frevo e seus "discos com as cores da cultura local", firmava-se "comercialmente por meio da grande audiência alcançada, atraindo patrocinadores." (SALDANHA \& CARRASCO, 2006, p. 158) chamando a atenção de gravadoras, como a RCA Victor ou a Odeon, impulsionando a produção fonográfica pernambucana.

Indicando uma operação conjunta dos meios de massa, argumenta o jornalista José Teles*, que à época também o Jornal do Commercio, fundado em 1919, participava da divulgação massiva do carnaval pernambucano, e por consequência dos artistas do frevo, dedicando à festa, dois suplementos semanais circulantes desde o mês de novembro do ano anterior. A esse respeito, Silva (1997) detalha que na década de 1930, as gravadoras do Rio de Janeiro, atinando para o mercado consumidor do Norte-Nordeste, iniciaram a gravação do frevo, chamando-o de marcha nortista. A organização do circuito difusor à época se valia da divulgação da Rádio Clube, de um produto musical originalmente local, sobretudo registrado e distribuído a partir de outro lugar, no caso a metrópole carioca.

A bibliografia consultada (TELES, 2000; SILVA, 1998) aponta que os frevos gravados na época soavam de maneira falsa, em especial aos ouvidos dos mestres do frevo Recifense, algo que "não combinava com a vibração dos frevos que se estava acostumado a ouvir nas ruas e salões." (SILVA, 1997, p. 23).

Tal momento de espraiamento do frevo coincidiu com a desativação dos engenhos que dariam origem aos novos bairros da cidade, conferindo outro desenho a sua mancha urbana (ANDRADE, 1979). Naquele contexto, em 1934 por meio do Decreto 374 instituiu-se um primeiro zoneamento do Recife, dividido em quatro Zonas: a zona principal,

\footnotetext{
10 Capiba começou as atividades musicais aos oito anos de idade tocando trompa. Cursou direito e foi funcionário do Banco do Brasil, ao mesmo tempo em que compôs mais de uma centena de músicas (SILVA, 1998). Todavia, afirma Teles (2000), apenas em 1959 com o LP “Capiba 25 Anos de Frevo”, é que, ao lado de Nélson Ferreira, o artista se tornou símbolo da música recifense. Por seu turno, Nélson Ferreira iniciou sua carreira como pianista em cafés noturnos e prostíbulos do Recife (SILVA, 2002) e viveu exclusivamente de música, como compositor, na Rádio Clube e como produtor artístico da gravadora Rozenblit. Destaca-se ainda Claudionor Germano, importante intérprete do frevo pernambucano.
} 
no entorno do porto, praticamente "uma subzona comercial" (BITOUN, 2000, p. 50), as zonas urbana e suburbana nas margens do Capibaribe, além da zona rural.

Nessa via, de reorganização da polis, entre os anos 1930 e 1950, propõe Alves (2008), ocorrera grande ebulição cultural na capital pernambucana, momento em que o "urbanismo" se tornara matéria de discussão social. A modernidade chegava ao Recife, seja no planejamento urbano e seus métodos, que incluía, entre outros, a reforma de praças e largos (ALMEIDA, 2005), ou na a verticalização das construções ocorrendo conjugada a destruição dos mocambos, precárias habitações, signo do pauperismo recifense.

No referente à rede urbana brasileira, a concentração industrial aumentava e, em 1938, São Paulo movimentava $43 \%$ do PIB nacional ao passo que $4,2 \%$ era o que cabia a Pernambuco. Sobre o fato, Singer (1968, p. 323) sentencia: “... no processo de formação do mercado nacional, ou seja, de unificação dos mercados locais, a primazia dos centros industriais mais fortes se acentua, em detrimento dos mais fracos, entre os quais se encontra Pernambuco."

No Recife, no mesmo ano de 1938, durante o governo de Agamenon Magalhães, criava-se o Plano de Erradicação de Favelas ${ }^{11}$. No ano seguinte, surgia a "Liga Social Contra o Mocambo", quando o Recife abrigava 45.521 dessas construções ${ }^{12}$ (MELO, 1978). Em cinco anos foram derrubados 12.434 mocambos e construídas 496 casas. Na ocasião o projeto de "limpeza" da urbe tomou enormes proporções, daí Filho (1953) afiançar que tal procedimento incluía os violeiros e repentistas do Recife que a exemplo de toda a população marginalizada recebiam frequentes reprimendas por parte do poder público:

\begin{abstract}
Uma vez por outra, no Recife, não é de hoje, o governo manda prender, a torto e a direito, mendigos de toda espécie, legítimos e falsos. Faz-se a correição, de quando em quando, mas não se cuida da prevenção aconselhada, de ordem social e de natureza cristã, amparando-se a velhice e a cegueira, em modos definitivos, evitando-se a propagação de moléstias infecto-contagiosas, limpando-se a cidade totalmente, dessa lastimável miséria humana, onde se incluem pessoas andrajosas, de corpo chagado, um quadro sensível a todos os corações, e humilhante para nossos foros de gente civilizada.
\end{abstract}

(FILHO, 1953, p. 172).

Inclusa nesse processo, na época, a tentativa por parte do poder público de diminuir a migração para a cidade passava por dar aos pobres urbanos uma passagem para o sudes-

\footnotetext{
${ }^{11}$ A respeito do planejamento urbano aplicado no Recife na época, Santana (2005, p. 31) afirma que os planos propostos “... se restringiram a propostas parciais de intervenção para remodelação e embelezamento nos bairros centrais”. Ainda sobre o tema, vale mencionar o Plano de Uchôa Cintra elaborado em 1943, que propõe aterramentos na bacia de Santo Amaro e a composição do sistema viário a partir de três perimetrais e seis radiais. O plano subsequente, centrado no sistema viário foi elaborado por Edgar Amorim.

12 Em 1939, viviam em mocambos cerca de 165 mil pessoas das quase 350 mil que compunham a população recifense (CASTRO, 1953).
} 
te do Brasil ou de volta para a zona rural nordestina. Falamos de um período chave para entender o processo de urbanização brasileira, um momento de inflexão que aponta para o desenvolvimento de um circuito de produção fonográfica melhor organizado no Recife.

\section{A ACELERAÇÃO DO FATO URBANO E O DESENVOLVIMENTO INICIAL DA INDÚSTRIA FONOGRÁFICA NO RECIFE (ANOS 1940-1965)}

O período de 1940-1950 é pontuado por Santos (1994 b) como momento decisivo da urbanização brasileira, aderindo à lógica de industrialização. Nesse período esboça-se a tecnificação de certos pontos do território e observa-se o predomínio dos nexos de uma industrialização sobre a dinâmica dos lugares.

Nesse propósito, Reynaldo (2005, p. 28) afirma os anos 1940 como o "início do processo de urbanização acelerada do Recife" com altas taxas de crescimento demográfico observadas até os anos 1970. A natureza desse crescimento da população associou-se a uma forte centralidade da capital pernambucana em relação ao seu entorno, no que tange aos fluxos, bens e serviços urbanos.

No referido período se intensificou a ocupação em áreas públicas e aumentou a repressão aos ocupantes marginalizados. Moura (1990) afirma que até os anos 1940 as terras recifenses foram ocupadas, em sua maioria, sob o consentimento dos proprietários em troca de zelo pela terra e aterramento dos alagadiços, momento em que os conflitos por uso da terra crescem na cidade.

Para melhor esclarecer o contexto do Recife da época, sistematizamos alguns elementos do território recifense (Tabela 1) apresentados por Freyre (1942) destacando os fixos e as atividades informacionais e materiais na cidade de outrora. 
Tabela 1 - Recife: elementos do território (1940)

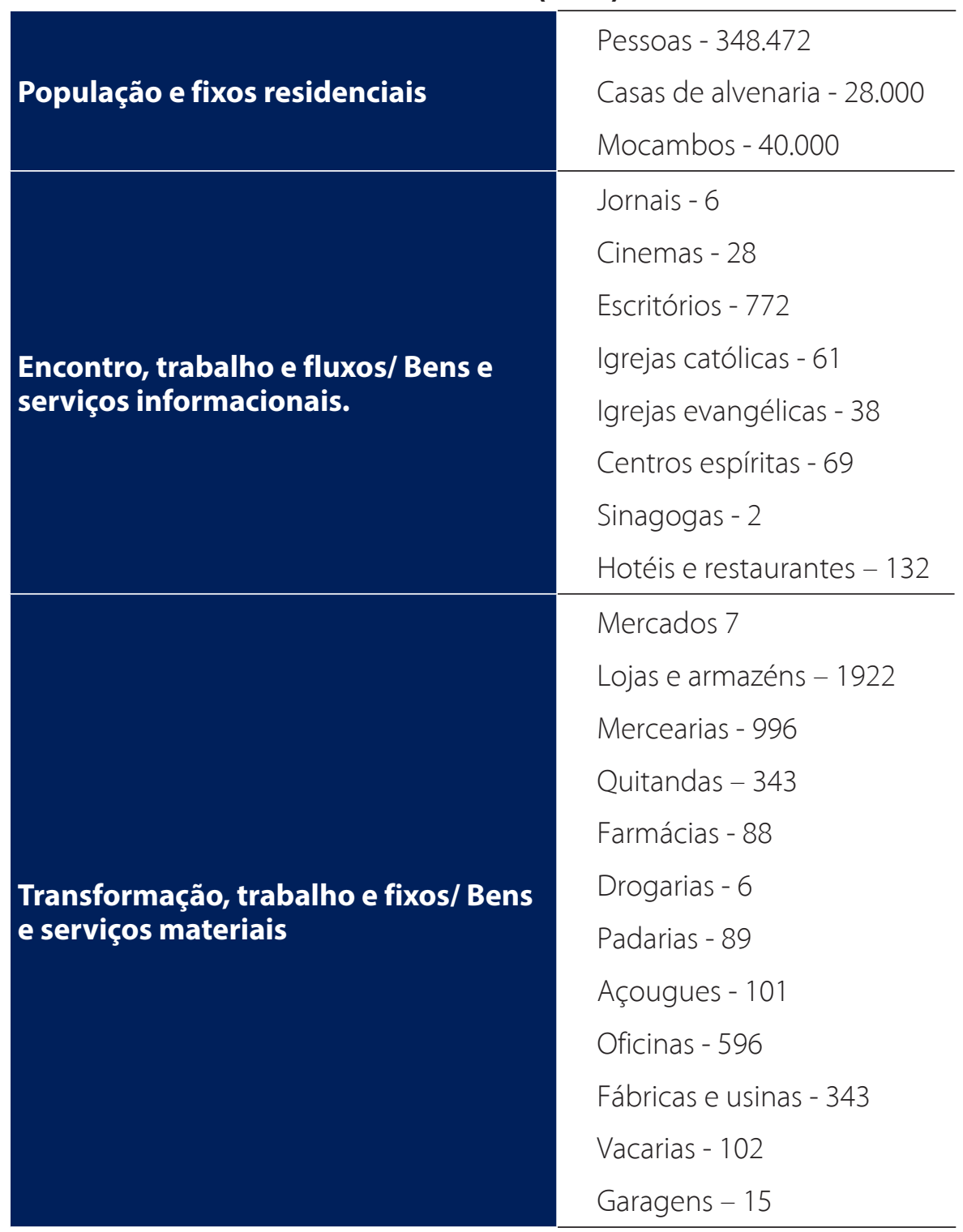

Elaboração própria, 2012. Informações em Freyre (1942)

No ano de 1940 a população do Recife chegou a 348.472 habitantes. Desse total, apenas 24.182 pessoas residiam na zona rural enquanto 21.874 pessoas trabalhavam no setor industrial, indicando um meio urbano consideravelmente tecnificado.

Chama-nos atenção ainda a apreciável espessura informacional recifense o que nos faz indagar, entre outros, a respeito das situações de encontro na urbe de ontem, de hoje e do amanhã. Sob os mercados e as quitandas, por exemplo, incidiriam uma série de círculos de cooperação manifestos em complexas situações e possibilidades de encontros e trocas em um cotidiano pleno de pessoas e eventos geográficos das mais diversas naturezas: 
"Além dos mercados, o Recife tem nos seus arredores feiras pitorescas. Muitos dos vendedores são matutos que trazem á cidade seu milho, suas frutas, suas cuias, farinheira e colheres de pau, seus chapéus de palha, seus tamancos" (FREYRE, 1942, p. 155).

Tais questões nos impõem retornar o foco para o Circuito Sonoro da época. Durante a década de 1940, ocorreu o adensamento do circuito em torno da música popular e surgiram as primeiras associações entre a imprensa escrita e a falada no país. Tratou-se do auge do rádio no Brasil, com o veículo servindo de importante meio homogeneizador cultural e formador de opinião pública. Na época, o Governo Federal advertia a importância do rádio como agente de enquadramento dos "ritmos selvagens" como o samba (SALGADO, 1941, p. 86).

Nessa direção, no ano de 1948, fora inaugurada a segunda emissora do Recife ${ }^{13}$, a Rádio Jornal do Commercio (prefixo PRL 6), então a mais potente das América Latina, concessão fruto de interesses dos poderes civis e militares em garantir, entre outros, que houvesse no nordeste uma emissora que servisse a defesa nacional (MORAIS, LIMA \& MARQUES, 2004). Para abrigar a emissora com uma programação musical e a presença marcante de programas de auditório, construiu-se na Estrada de Santana o "Palácio do Rádio", luxuoso prédio com “dois estúdios, um auditório para 750 pessoas, restaurante, dancing, entre outros espaços" (OLIVEIRA, 2011, p. 3), além de oito transmissores, alcançando diferentes países ${ }^{14}$. Teles (2003) explica que a rádio Jornal do Commercio deu início a montagem de uma cadeia de informação composta por uma série de emissoras, que incluía ainda uma emissora de televisão ${ }^{15}$.

O Recife impulsionado pela concorrência entre as duas emissoras, conheceu então um tempo marcado pela elevação da qualidade de seus programas radiofônicos e por um maior intercâmbio com artistas e técnicos do eixo Rio-São Paulo, repercutindo em uma intensa movimentação da produção musical na capital pernambucana. Nesse contexto, nos meses de setembro ou outubro de cada ano, os representantes das gravadoras com matriz no Rio de Janeiro e em São Paulo, instituíam um concurso entre os autores de frevo. A partir daí, os lojistas recifenses formavam um júri que escolhia as melhores músicas garantindo a compra de três mil unidades como condição para a gravação (TELES, 2003).

${ }^{13}$ Fato pouco citado na bibliografia Paiva (1996) afiança ainda a atividade na época, de outra emissora, chamada "Rádio Station" situada no Ibura.

${ }^{14}$ Organizada nos departamentos musical, de radioteatro, técnico e comercial, tendo como patrocinadores, entre outros, as Casas Ramiro Costa, a Fratelli Vita, a Coca-Cola, a Brahma e a Antarctica (MORAIS, LIMA \& MARQUES, 2004), a emissora, cujo alcance ultrapassava os limites do território nacional, segundo Teles (2000) foi montada com equipamentos dos mais avançados da época comprado juntos à fábrica inglesa Marconi’s Wireless Telegraph.

15 Para melhor entender a dinâmica dos grandes grupos de informação do Recife de então, lançamos mão de Teles (2003, p. 20), quanto este afirma que a instalação da Rádio Jornal do Commercio marcava o "surgimento de um complexo de comunicação, fundado por Francisco Pessoa Queiroz, que, até meados dos anos 60, seria um dos mais importantes do País, com potentes emissoras de rádio, sólidas estações de TV. Competiam com a TV e emissoras Jornal do Commercio, a potente Rádio Clube de Pernambuco e a TV Rádio Clube, pertencentes ao poderoso Diários Associados, de Assis Chateaubriand.' 
No ano de 1950 a população do Recife era de 535 mil habitantes e a cidade, a mais importante da região nordeste. Miranda (2004) lembra que o processo de metropolização do Recife remonta aos anos de 1950. Entre 1950 e 1975 intensificou-se a ocupação nas áreas periféricas do Recife com o aprofundamento do papel dos subcentros urbanos da metrópole e a consolidação da zona sul como vetor expansão da mancha urbana (PAIVA, 1996). Mediante um contexto de estagnação e intenso afluxo de pessoas, o poder público atuou no sentido de alargar a industrialização recifense, atenuando assim a estagnação da capital pernambucana inserida no secular processo de decadência nordestina (FURTADO, 1974) ${ }^{16}$.

Não por acaso, nos anos 1950, surgiu o estudo de Baltar (2000 [1951]) "Diretrizes de Um Plano Regional para o Recife". O plano, baseado no zoneamento urbano, trata da questão metropolitana ${ }^{17}$ a partir da concepção do Recife em relação com o seu entorno de "cidades satélites".

Baltar (2000 [1951], p. 79) lembrava que o Recife de então caminhava para ser uma metrópole sem perder ainda o seu "tom provinciano" abrigando uma série de deficiências que expunham uma crise de crescimento, resultante da:

... falta de base econômica sólida e definida para os seus brilharetes urbanos, que tanto se traduzem na profusão de bungalows e arranha-céus em miniatura, como em carros luxuosos às centenas, amontoando-se em suas novas avenidas e contrastando, uns e outros, violentamente com a miséria generalizada em cerca de metade da população.

A desigualdade socioterritorial associada ao crescimento da aglomeração, resultado do afluxo de uma massa populacional para um lugar sem condições de recebê-la ofertando-lhe os bens e serviços necessários, tampouco abrigo de um mercado capaz de absorver esta mão de obra, acarretou a expansão dos pequenos circuitos da economia no Recife:

Não havia infra-estrutura suficiente para atender a todos, muito menos empregos, pois a capacidade industrial dos municípios não ofereciam trabalho suficiente. Restavam os setores de comércio e serviços, que abrigavam o biscateiro, o estivador, o vendedor ambulante, etc... formas mais comuns de engajamento para os que, sem qualificação profissional, se aventuraram no sonho da cidade grande"

(BARRETO, 1990, p. 85)

16 Sobre a questão, Furtado (1974, p. 240-241) explica: "A decadência da região nordestina é um fenômeno secular, muito anterior ao processo de industrialização do sul do Brasil. A causa básica daquela decadência está na incapacidade do sistema para superar as formas de produção e utilização dos recursos estruturados na época colonial. A articulação com a região sul, através de cartelização da economia açucareira, prolongou a vida ao velho sistema cuja decadência se iniciou no século XVII, pois contribuiu para preservar as velhas estruturas monoprodutoras."

17 Baltar (2000 [1951]) apresenta uma análise dos planos urbanos para o Recife apresentados por Nestor Figueireido (1932), Fernando Almeida (1932), Atílio Lima (1934) e Ulhôa Cintra (1942), destacando que nenhum deles considerou a perspectiva regional. O autor supracitado, entre outros, sublinha a necessidade de preservação do patrimônio cultural do meio ambiente construído frente à expansão da urbe e do fato consumado nesse processo: a conurbação entre Recife, Olinda e Jaboatão. 
Acompanhando o processo de metropolização desigual nos anos 1950, observou-se o adensamento do Circuito Sonoro. No início da década instalava-se na capital pernambucana a Rádio Tamandaré com uma programação eclética, composta por novelas, radioteatro, música e futebol; abrigada em um terreno doado pela Prefeitura do Recife ${ }^{18}$, na esquina da Rua do Imperador com a Rua Marquês do Recife.

Na cidade em crescimento, além do circuito de radiodifusão colaborava para o adensamento musical nos anos 1950 o fato dos aviões de carreira vindos da Europa não terem autonomia de voo, sendo o Recife escala obrigatória ${ }^{19}$ para músicos eruditos em direção aos grandes centros musicais da América do Sul: Rio de Janeiro, Buenos Aires, São Paulo e Montevidéu. Essa circunstância punha a cidade na rota das atrações da música erudita internacional, recebendo solistas, orquestras ou corais que após horas de viagem, não raro se apresentavam no Teatro Santa Isabel próximo aos hotéis (ALMEIDA \& SCARPA, 2002).

Na mesma década de 1950 um amplo sistema de gravação disseminou-se por toda a indústria fonográfica com procedimentos de isolamento acústico, distribuição e separação de microfones, participação do engenheiro de som, desenvolvimento do sistema estéreo, entre outros (VICENTE, 1996).

Fora quando se projetou nacionalmente o pernambucano Luiz Gonzaga que, no Rio de Janeiro, em parceria ${ }^{20}$ com Humberto Teixeira, definiu as linhas sob a qual se assentaria o baião, gênero musical tocado com a sanfona, a zabumba e o triângulo, e que antes da dupla designava uma batida de violas dos lundus no interior do nordeste.

A difusão desse estilo, a partir do Rio de Janeiro, implicou em um circuito de produção espalhado por diversos lugares da região nordeste, sobretudo em Pernambuco: "Com a estilização de vários ritmos apreendidos no Araripe por Luiz Gonzaga, começaram a surgir no Nordeste compositores especializados em ritmos da região" (TELES, 2003, p. 25).

O exame do Circuito Sonoro recifense, no início dos anos 1950 aponta que a cidade contava com 16 lojas de discos, entre outras, a Loja Bom Gosto, da família Rozenblit, localizada inicialmente na Rua da Palma no centro e depois na Rua da Aurora. Nesse fixo instalou-se um mini estúdio, no qual era possível realizar pequenas gravações, um dos pioneiros do Recife:

18 Lei Orgânica Municipal nº 1249 de 22 de junho de 1951.

19 O jornalista José Teles nos contou em entrevista* que existiam até mesmo os repórteres de aeroporto com a função de documentarem a presença dos artistas vindos em curtas escalas ao Recife.

20 De acordo com Teles (2003) no ano de 1949 no Pina em Recife, Luís Gonzaga conheceria Zé Dantas, outro importante parceiro musical. Expressiva a passagem sobre a trajetória do "Rei do Baião" oferecida por Ratis (2004, p. 3): "Saiu de casa em 1930 para servir o exército como voluntário. Viajou pelo Brasil como corneteiro, deu baixa em 1939 e resolveu ficar no Rio de Janeiro. Tinha como grande bem uma sanfona recém-comprada. Passa então a se apresentar em ruas, bares e mangues, tocando boleros, valsas, canções, tangos. Sabia que o rádio em 1941 era o melhor vínculo de divulgação musical e assim resolveu participar do concurso de calouros de Ary Barroso." 
... era por causa dos discos importados que o estabelecimento se destacava. A loja era dotada de seis cabinas, onde o cliente podia escutar os álbuns antes de decidir se os comprava ou não. Frequentemente ali se promoviam exposições de artistas plásticos locais. Um dos serviços que oferecia aos clientes era algo raro no país então: uma cabina especial onde funcionava um mini-estúdio, no qual tanto se podiam gravar jingles quanto registrar a própria voz em acetato. (TELES, 2000, p. 18).

Idealizada por João Rozenblit em 1953 surgiu a gravadora Rozenblit, que se expandiu a partir do lançamento de discos regionais, em especial o frevo ${ }^{21}$, chegando a ter filiais no Rio de Janeiro, em São Paulo e no Rio Grande do Sul, sendo responsável por “dezena de fonogramas fundamentais para a história da música brasileira" (TELES, 2000, p. 18) a partir dos selos "Mocambo", especializado em música pernambucana e regional e "Artistas Unidos”, com um catálogo de frevo, forró, samba, música orquestral, jazz e blues (TELES, 2003).

No final daquele ano de 1953 se instalaria na Rua do Bonfim no Alto da Sé a Rádio Olinda, sob influência do então Governador de Pernambuco, Agamenon Magalhães (MORAIS, LIMA \& MARQUES, 2004). O Recife, com quatro emissoras de rádio e uma gravadora passava a ter os frevos gravados na própria cidade, com cuidados maiores em relação aos seus conteúdos formais, tais quais, andamento, timbre, textura, dinâmica, entre outros. Nesse contexto não apenas os artistas do frevo, mas de outros estilos se beneficiavam do fato de poderem produzir seus registros fonográficos no próprio Recife.

Em 1954 a gravadora Rozenblit, com capital próprio ampliou suas instalações no Recife, abarcando diversas etapas da produção fonográfica, inclusive com uma fábrica de discos localizada da Estrada dos Remédios em Afogados. O produtor Hélio Rozenblit*, filho de João Rozenblit, fundador da gravadora, nos falou um pouco a respeito da estrutura da empresa: "ela tinha três galpões imensos e mais um estúdio que era um prédio enorme com piano..." e um gravador AMPEX, hoje propriedade do produtor Dário do Estúdio Revelações, situado em Santo Antônio.

Ainda a respeito da fábrica de discos Rozenblit, Teles (2000, p. 71) explica:

... a Fábrica (...) foi instalada em um terreno de 14.000 m, na Estrada dos Remédios, bairro de Afogados, a dez minutos do centro da capital pernambucana. Era dotada de um dos mais modernos estúdios da América do Sul, único, aliás, no Brasil da época a ser construído com esta finalidade, com espaço interno suficiente para abrigar uma grande orquestra. Auto-suficiente em tudo, com a óbvia exceção do acetato, importado dos EUA, a gravadora dispunha de um moderno parque gráfico que lhe dava autonomia em imprimir capas, material de divulgação e prensar seus próprios discos.

${ }^{21}$ Lembra Teles (2003, p. 40), que em seu auge, a produção da Rozenblit respondia por um terço da programação das emissoras pernambucanas "e a gravadora chegou a ser dona de metade do mercado regional de discos." 
Para melhor compreender o Recife e o seu papel na rede urbana da época, lembramos que, conforme Melo (1974), até 1950 a economia nordestina estava baseada na cidade, que respondia por 26,2\% de seu produto. Durante a década de 1950 aconteceu expressivo crescimento da população abrigada na área que daria origem a Região Metropolitana de Recife (RMR) - instituída em 1973 - , passando de 652.116 pessoas no ano de 1950 para 1010.026 pessoas no ano de 1960. Signo da aglomeração que adquiria maiores proporções, aumentaria ainda no período os movimentos e organizações populares como a "Frente do Recife" composta pelos partidos PSB, PTB e PCB, este apesar de estar então na clandestinidade (ALBUQUERQUE, 1995). No contexto regional mais amplo, ao longo da década de 1950, ocorrera a instalação da hidrelétrica de Paulo Afonso, importante macro sistema técnico para a região nordeste e começa a operar sediada em Recife, a SUDENE (Superintendência de Desenvolvimento do Nordeste) visando o crescimento industrial da Região, com investimentos alocados em sua maior parte na Bahia e no Pernambuco.

A esse termo, no ano de 1961 institui-se a Lei 7.427, marco normativo decisivo para a evolução da urbe recifense ${ }^{22}$, dividindo a cidade em três zonas: urbana, suburbana e rural. Destaca-se que a zona suburbana fora subdivida em zona universitária, residencial, portuária, comercial e três zonas industriais. Seguindo o corolário assumido pela urbanização brasileira desde os anos 1950, adotava-se no Recife a opção por um crescimento pautado na industrialização do território. Para Bitoun (2000) esse marco normativo implicou em uma profunda transformação do ritmo de crescimento ocorrido desde os anos 1940 no Recife. Em relação ao decreto de 1934, o marco normativo anterior, o autor supracitado pontua as seguintes mudanças:

O setor urbano é estendido para o oeste, onde integra porções do antigo espaço suburbano (Encruzilhada, Madalena, Afogados), e para sul, onde incorpora a orla de Boa Viagem. O setor suburbano é o maior e, para poder estruturá-lo no sentido de uma urbanidade mais completa, propõe instituir núcleos urbanos. Em fim, o setor rural ocupa as extremidades oeste e noroeste do município.

(BITOUN, 2000, p. 51).

Nesse princípio da década de 1960, momento inicial da difusão do meio-técnico-científico no país (SANTOS, 1994 b), o Recife atingia uma população de 797 mil pessoas enquanto a sua região passaria a ter cerca de 1.740.000 habitantes. Na aglomeração recifense, o período foi rico em experiências musicais. Na capital pernambucana que assumia ares de metrópole, agia um grupo de articuladores sonoros, responsáveis pelas atividades de um circuito em ebulição e diferentes informações musicais circulavam na polis.

22 Para mais informações sobre urbanismo e planejamento urbano no Recife no período até os anos 1950, consultar Pontual (1999 e 2005). 
Sob o tema da circulação de informação sonora no território, cabe lembrar que nesse período surgiu o instrumento normativo que ainda hoje regula a radiodifusão no país, o Código Brasileiro de Telecomunicações (CBT), baseado na Lei 4.117 de 27 de agosto de $1962^{23}$. Lopes (1997) afirma se tratar de um sistema de concessões autoritário e concentrado, sem qualquer impedimento para a formação de oligopólios ou monopólios. Gomes (2001, p. 346) explica que nos anos 1960 se inicia no território brasileiro a implantação dos primeiros sistemas de "transmissão de sinais á distância".

Não por acaso, ocorreu no Recife desde o final dos anos 1950 um primeiro adensamento do Circuito Sonoro em sua relação com os meios de informação de massa, fenômeno que perpassou os anos 1960, compreendendo a chegada das emissoras de TV e o incremento do circuito de rádio na capital pernambucana (Quadro 1).

No início dos anos de 1960, período de "consolidação da integração das indústrias culturais no Brasil” (GOMES, TROTTA \& LUSVARGHI, 2010, p. 24) entrava em operação o segundo estúdio fonográfico do Recife, localizado no Conservatório Pernambucano de Música em Santo Amaro, realizando gravações em dois canais apenas para as demandas da instituição.

À época, enquanto no interior de Pernambuco ainda eram comuns as serenatas, na capital além da Rozenblit, operava a fábrica de vitrolas ABC "A Voz de Ouro", e uma gravadora de menor porte: a Capibaribe, que segundo o jornalista José Teles ${ }^{\star}$, vinha para suprir, em especial a procura dos mais jovens por música.

Nesse contexto reuniam-se músicos e agitadores culturais de diversas vertentes ${ }^{24} \mathrm{em}$ lugares como o Bar Aroeira na Boa Vista. Havia os tropicalistas sob a influência de Jomard Muniz de Brito, importante agitador recifense. Nessa via Gilberto Gil (2001) explica a proposta de unir os Beatles e a banda de pífanos de Caruaru e a vontade do tropicalismo de entrecruzar escalas territoriais, lugares e sonoridades, acompanhando em certo sentido o movimento do fato urbano.

${ }^{23}$ O CBT definiu a radiodifusão como espécie de serviço de telecomunicação "destinado a ser recebido direta ou indiretamente pelo público em geral, compreendendo radiodifusão sonora e TV.” A Constituição Federal de 1988, por sua vez, em seu capítulo V do Título VIII, referente à "comunicação social", reafirma o teor do CBT e estabelece como competência da União a exploração e concessão "dos serviços de radiodifusão sonora, de sons e imagens e demais serviços de comunicação" (Artigo $5^{\circ}$ - IX), porém agora definindo o Congresso Nacional como única instância capaz de atribuir, renovar ou cancelar concessões de rádio e TV (Artigo 49 - XII), competência antes exclusiva do poder executivo. Ferrareto (2001) informa que as categorias trabalhistas envolvidas na empresa de radiodifusão compreendem jornalistas, funcionários administrativos e radialistas: (Lei $\mathrm{n}^{\circ} 6.615$, de 16/12/1978 - Decreto ${ }^{\circ} 84.134$ de 30/10/1979).

${ }^{24}$ Entre os músicos e agitadores da cena do Recife da época, Teles (2000) destaca Marcelo Melo e Toinho Alves (fundadores do Quinteto Violado), Zélia Barbosa, Geraldo Azevedo, Naná Vasconcelos, Laboratório dos Sons Estranhos, Teca Calazans, Carlos Fernando, e Sebastião Vila Nova. 


\section{Quadro 1 - Meios de informação de massa e Circuito Sonoro. Adensamento do circuito de rádio/ chegada da TV ao Recife (1957-1963)}

\begin{tabular}{|c|c|c|c|}
\hline Ano & Meio de informação & $\begin{array}{l}\text { Localização (sede/ } \\
\text { transmissão) }\end{array}$ & $\begin{array}{l}\text { Agentes/ Grupos de } \\
\text { informação envolvidos }\end{array}$ \\
\hline 1957 & Rádio Capibaribe & $\begin{array}{l}\text { Rua Coronel Ribeiro } \\
\text { Sena, Cajueiro }\end{array}$ & $\begin{array}{c}\text { Oscar Moreira Pinto, D. } \\
\text { Antônio Almeida de Moreira } \\
\text { Júnior (Arcebispo de Olinda } \\
\text { e Recife), Miguel Vita e Cân- } \\
\text { dido Vita Sobrinho }\end{array}$ \\
\hline \multirow{2}{*}{1958} & \multirow{2}{*}{ Rádio Continental } & $\begin{array}{l}\text { Estúdio: Rua da } \\
\text { Palma - Centro }\end{array}$ & \multirow{2}{*}{$\begin{array}{l}\text { TV Continental do } \\
\text { Rio de Janeiro }\end{array}$} \\
\hline & & $\begin{array}{l}\text { Transmissores: } \\
\text { Jardim São Paulo }\end{array}$ & \\
\hline 1960 & TV Rádio Clube & $\begin{array}{l}\text { Rua Capitão Lima 250, } \\
\text { Santo Amaro }\end{array}$ & Diários Associados \\
\hline 1960 & TV Jornal & $\begin{array}{c}\text { Rua do Veiga, Santo } \\
\text { Amaro }\end{array}$ & Grupo Jornal do Commercio \\
\hline 1962 & $\begin{array}{c}\text { Rádio Repórter } \\
\text { (tornada Rádio Globo) }\end{array}$ & Bomba do Hemetério & $\begin{array}{c}\text { Hosano de Albuquerque } \\
\text { Braga e Júlio Gerson de } \\
\text { Carvalho }\end{array}$ \\
\hline \multirow{2}{*}{$\begin{array}{c}1963 \\
(1968- \\
\text { Entrada } \\
\text { em } \\
\text { operação) }\end{array}$} & \multirow{2}{*}{ Rádio Universitária } & $\begin{array}{c}\text { Estúdio/ produção - } \\
\text { Rua do Hospício }\end{array}$ & \multirow{3}{*}{$\begin{array}{c}\text { Universidade do Recife } \\
\text { (Hoje Universidade Federal } \\
\text { de Pernambuco) }\end{array}$} \\
\hline & & $\begin{array}{c}\text { Transmissores - Campus } \\
\text { do Engenho do Meio }\end{array}$ & \\
\hline 1968 & TV Universitária & Avenida Norte & \\
\hline
\end{tabular}

Informações em Morais, Lima \& Marques, 2004. Elaboração própria, 2014.

Teles (2000, p. 101) considera que no Recife, em João Pessoa e em Natal, um movimento tropicalista "foi deflagrado quase que simultaneamente ao dos baianos em São Paulo..." ${ }^{25}$ No Bar do Alves no Bairro da Encruzilhada em Recife, afirma o autor supracitado, fora redigido o Manifesto tropicalista: "O Que é o Nosso Tropicalismo ou Vamos Desmascarar o Nosso Subdesenvolvimento”, com a participação de figuras como Jomard Muniz de Britto, Will Leal, Carlos Aranha, Martinho Moreira Fraga, Raul Córdula, Marcus Vinicius ao som dos Quatro Loucos grupo do qual fazia parte o músico paraibano Zé Ramalho.

${ }^{25}$ Segundo Teles (2004, p. 19) em Pernambuco o tropicalismo, movimentação da qual não se tem nenhum registro audiovisual “... abrangia poesia (o poema-processo), pintura. O movimento era divulgado no Jornal do Commercio, onde militava o tropicalismo Celso Marconi, que abria espaço para o amigo Jomard Muniz de Britto. As elucubrações tropicalistas eram colocadas em prática com o grupo LSE (Laboratório de Sons Estranhos), cujas apresentações inevitavelmente terminavam em happenings, com participação de toda a plateia." 
Destacam-se ainda os militantes do Movimento de Cultura Popular, e do Movimento Armorial, fundamentado na manutenção da tradição cultural pernambucana, composto por Ariano Suassuna, Hermilo Borba Filho, Paulo Freire, o maestro Cussy de Almeida, o grupo Quinteto Violado, entre outros.

Durante um período de intensa repressão por parte do governo militar, um conjunto de fatores contribuíram para a rarefação do circuito tropicalista pernambucano. Importantes articuladores, como Geraldo Azevedo e Naná Vasconcelos migraram do Recife; além disso, a repressão aumentava no Recife, em virtude da ação dos paramilitares do CCC Comando de Caça aos Comunistas (TELES, 2000) e do golpe militar de 1964, que entre outros, implicou no "refluxo nas organizações populares" (COUTINHO, 1989, p. 58), em franca expansão desde meados dos anos 1950 no Recife.

Lima \& Guillen (2007) elucidam que, nessa década de 1960, enquanto os maracatus definhavam, os populares se agregavam aos clubes e blocos de frevo, e às escolas de samba. A desproporção chegou ao ponto dos maracatus reunirem quarenta pessoas enquanto milhares pulavam o carnaval. Tal afirmação dá ideia de como funcionavam os fluxos do Circuito Sonoro em suas diversas manifestações no Recife dos anos 1960.

O Recife apresentava o esboço inicial de um Circuito Sonoro pautado na esquizofonia, com sete emissoras de rádio, cinco delas localizadas na área central, a gravadora Rozenblit situada em Afogados, e o Beco Barato, na Boa Vista, funcionando como ponto de convergência para os agitadores culturais de então (Figura 1). 
Figura 1 - Estúdio fonográfico, emissoras de rádio e lugar de encontro musical - Recife, 1965.

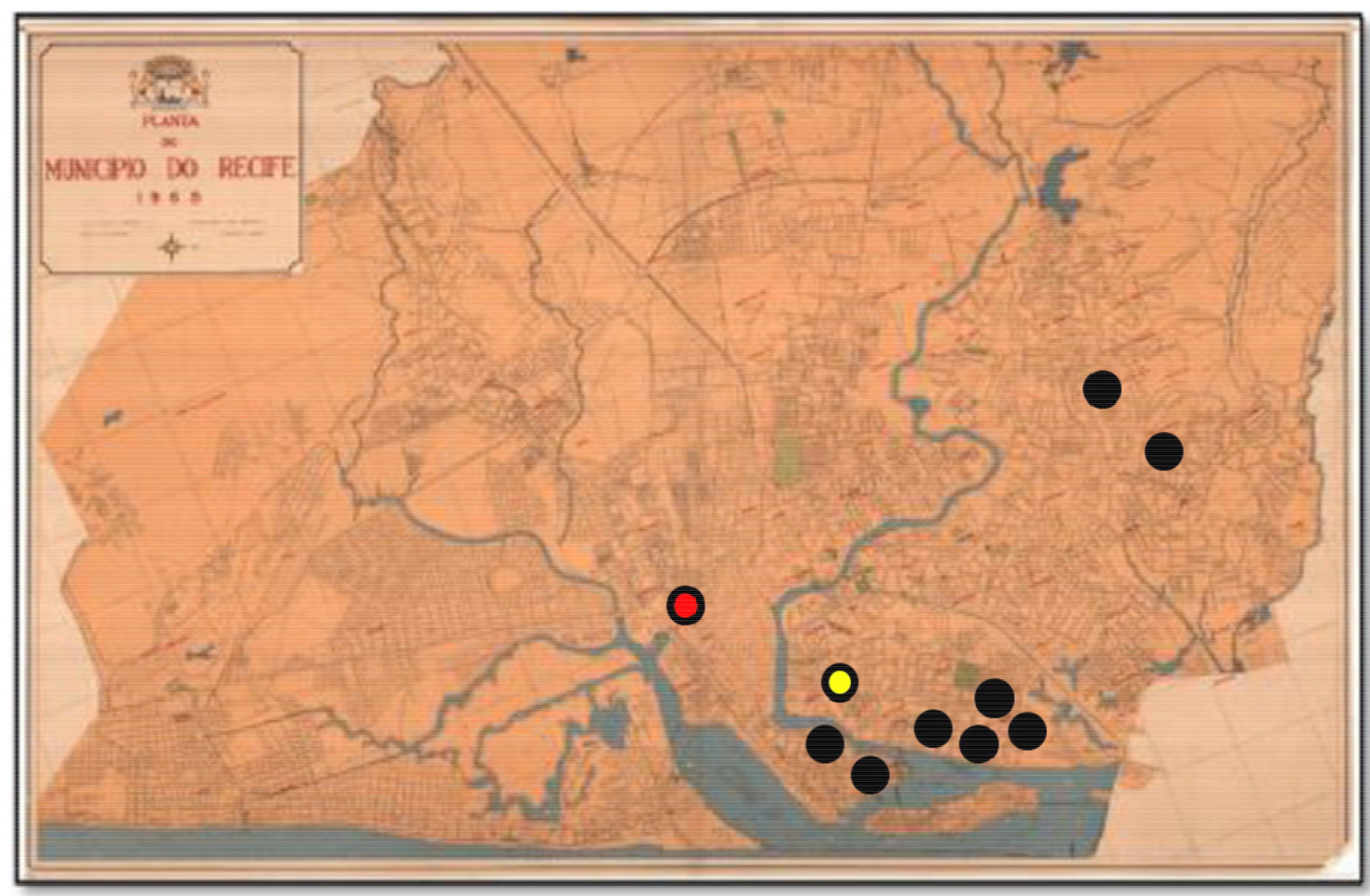

BECO DO BARATO

Elaboração: Autor

Base de referência: Planta do município do Recife, 1965.

Fonte: CONDEPE/FIDEM In A. BORBOREMA, H. ANDRADE, e L. MARQUES DE SÁ (2011)

A ebulição no Recife na época não se restringiu apenas aos circuitos culturais, compreendeu ainda os conflitos pela terra urbana. No início dos anos 1960, quando o Recife padecia com a falta de investimentos por parte do governo federal, estimava-se que os mocambos compreendiam quase 60\% das habitações existentes. A cidade no ano de 1966 sofreu uma grande cheia acarretando muita destruição e deixando quase um terço dos chefes de família sem renda.

Conforme Moura (1990) observou-se nos anos 1960 um segundo momento de acirramento dos conflitos em ocupações e invasões de terras no Recife. No período espraiou-se a "estratégia informal para atender a própria demanda habitacional" (IDEM, p. 66) aplicada por uma "classe de baixa renda, contrariando as leis de mercado e a produção oficial de habitações" (IBIDEM) e que implicou, entre outros fatores, na construção dos primeiros e insalubres conjuntos habitacionais periféricos. Não por acaso, o Banco Nacional de Habitação-BNH tornou-se agente de grande importância para o entendimento das políticas habitacionais na cidade (ALVES, 2008). 
Tratou-se da situação na qual se avolumou a ação da produção musical recifense, momento ainda da regulamentação do circuito de Rádio de FM no Brasil e da gênese do que viria a consolidar-se como o meio técnico-científico informacional.

\section{CONSIDERAÇÕES FINAIS}

Em que medida a cidade produz e é produzida pela variável sonora? O que pode se revelar por meio da análise do fato urbano e da produção musical? Menos que responder tais questões, o que buscamos aqui, por meio de uma proposta de periodização do Circuito Sonoro recifense, fora, analisar a dinâmica socioterritorial da urbe, problematizando a circulação de informações sonoras e musicais ao longo de um período no qual os sistemas técnicos informacionais, paulatinamente se tornam parte da vida dos lugares.

O Circuito Sonoro, maleável, em constante mudança, base e implicação do fato urbano demonstra como na capital pernambucana ao longo do tempo se adensaram materialidades e ações em torno do componente musical e sonoro. Trata-se de uma ferramenta de natureza teórico-empírica com capacidade para auxiliar na tarefa de compreender o modo como a cidade é construída a partir da música e do som. Isto, pois o Circuito Sonoro, retrato da historicidade dos lugares, substanciado por toda uma espessura de objetos/sistemas técnicos e fluxos, contribui para a manutenção e a reorganização da dinâmica urbana. Mediante a análise das variáveis que constituem o circuito sonoro (emissoras de rádio, estúdios fonográficos, lojas de discos, ensaios e apresentações de grupos musicais, fluxo de informação embutido, entre outros) a um só tempo examina-se o movimento intra-urbano bem como a articulação da urbe com alhures.

A periodização proposta indica que no final do século XIX, o Recife com bondes, linhas de trem e jornais, sofrera um primeiro impulso industrializante, momento marcado pela chegada do fenômeno esquizofônico e o surgimento do frevo, sinalizando para a ebulição da classe trabalhadora.

No início do século XX o surto industrial inibiu-se e a cidade, envolta em projetos de renovação urbana e os estridentes sons da destruição-reconstrução do meio ambiente construído, abrigava a chegada das vitrolas e da radiodifusão, alterando por completo a relação entre som, fricção de distância e uso do território.

Nos anos 1940, momento decisivo para a urbanização brasileira, acirrava-se no Recife a expulsão dos pobres urbanos, intensificando-se a repressão aos ocupantes de ter- 
ras, aprofundando-se a segregação e a fragmentação da cidade. Parte desse período de cisão territorial dá-se a chamada "era de ouro" das emissoras de rádio, duas delas operando no Recife, momento no qual as lojas de discos e os aparelhos receptores de rádio se difundem na polis.

Nos anos 1950, momento de reconfiguração da mancha urbana, com a criação de novos bairros, surgiu a primeira gravadora da capital pernambucana, a Rozenblit, e os fonogramas de artistas locais, até então produzidos no Rio de Janeiro, passaram a ser elaborados na própria cidade. Assim, por meio da produção fonográfica, revelam-se os nexos entre a hierarquia da rede urbana brasileira e o controle de uma informação estética fundada nos lugares, fruto de suas práticas.

Na década seguinte de 1960, observou-se o crescimento dos mocambos retratando a desigualdade socioterritorial em curso na metrópole do Recife. Ocorreu igualmente nessa época a criação do Código Brasileiro de Telecomunicações, norma centralizadora e conivente com o monopólio da informação. Eis a ocasião na qual a capital pernambucana abrigava uma série de férteis experiências musicais em torno do Tropicalismo e do Movimento Armorial, postura que permaneceu em voga, mesmo sob a repressão instalada com o golpe militar de 1964, fazendo coincidir no Brasil a aurora do meio técnico-científico informacional e um período de autoritarismo incidindo sobre o país.

\section{REFERÊNCIAS}

1. ADORNO, Theodor W. Indústria cultural e sociedade. São Paulo: Paz e Terra, 2004 [1947].

2. ALBURQUERQUE, Wilson Naurício Miranda. Novas práticas de urbanização nas periferias do Recife: As comissões de acompanhamento de obras. Mestrado, Geografia, Universidade Estadual de Pernambuco. Recife, 1995.

3. ALMEIDA, Cussy \& SCARPA, Paulo Sérgio. Palco vazio. Continente Multicultural. II (17): 74-77, maio 2002.

4. ALMEIDA, Érica Audet de Almeida. A articulação dos espaços públicos na paisagem do Recife através da evolução urbana. (116-145 p.) In PONTUAL, Virgínia \& CARNEIRO, Ana Rita Sá (orgs). História e paisagem: ensaios Urbanísticos do Recife e de São Luís. Recife: Bagaço, 2005.

5. ALVES, Cristiano Nunes. Radiodifusão, produção fonográfica e espaço urbano: formação e adensamento do fenômeno esquizofônico em Campinas-SP (... 1990). Revista Rua. Campinas, $\mathrm{n}^{\circ} 16$ - Volume 2, Novembro 2010. Pp. 37-63.

6. ALVES, Henrique Vitorino Souza Et all. O complexo turístico cultural Recife- Olinda: ide-

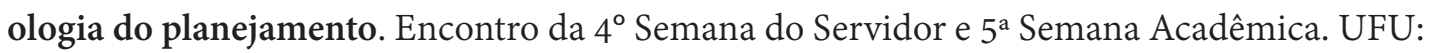
Uberlândia-MG, 2008. 10 pp. 
7. AMORIM, Luiz \& LOUREIRO, Claudia. As traças do Recife: um ensaio sobre um mosaico de cores, de cheiros e de sons. Arrecifes. Revista do Conselho Municipal de Cultura, Recife, 29 (9): 75-81, dez. 2004.

8. ANDRADE, Manoel Correia de. Recife - Problemática de uma metrópole da região subdesenvolvida. Recife: Editora Universitária - UFPE, 1979.

9. ARAÚJO, Rita de Cássia Barbosa de. Máscaras do tempo: entrudo, mascarada e frevo no carnaval do Recife. Recife: Fundação da Cidade do Recife, 1996.

10. ARROYO, Mónica. Território, transição e futuro. Revista Experimental, n 1, 1996. Pp. 77-85.

11. BALTAR. Antônio Bezerra. Diretrizes de um plano regional para o Recife. Recife: Editora Universitária-UFPE, 2000 [1951].

12. BARRETO, Angela Maria Maranhão. O Recife através dos tempos (formação de sua paisagem). Mestrado, Geografia, Universidade Estadual de Pernambuco. Recife, 1990.

13. BITOUN, Jan. Regulamentações e dinâmica das localizações comerciais no Recife (Brasil). Revista de Geografia Recife: UFPE, 16 (1): 157-168 jan./jun. 2000.

14. BORBOREMA, Ana Cláudia Bezerra de Albuquerque; ANDRADE, Henrique José Lins Ferreira \& MARQUES DE SÁ, Lucilene Antunes Correia. Da Cartografia dos Antigos Engenhos à Cartografia Holandesa e Portuguesa. Anais do $1^{\circ}$ Simpósio Brasileiro de Cartografia Histórica. Parati-RJ, 10 a 14 de maio de 2011. 18 páginas.

15. CASTRO, Josué. A Cidade do Recife: ensaio de geografia urbana. Rio de Janeiro: Livrariaeditora da casa do estudante do Brasil, 1953.

16. CONNERTON, Paul. A Memória Social. In: Como as Sociedades Recordam. Oeiras: Celta Editora, 1999.

17. CORREAA, Armando. A aparência, o ser e a forma (geografia e método). GEOGRAphia, ano II, n 3, 2000. Pp. 7-25.

18. COUTINHO, Maria Cristina. As transformações do/no projeto Recife - redirecionamento no espaço: uma análise da relação entre planejamento urbano e movimento popular. Mestrado, Geografia, Universidade Estadual de Pernambuco. Recife, 1989.

19. DOLLFUS, Oliver. A análise geográfica. São Paulo: Difel, 1973.

20. DOLLFUS, Oliver. “Geopolítica do Sistema-Mundo”. In: Santos, M. et al (orgs). O Novo Mapa do Mundo. Fim de Século e Globalização. SP: Hucitec/Anpur, 1993. Pp. 23-45.

21. FERRARETO, Luiz Artur. Rádio: o veículo, a história e a técnica. Porto Alegre: Sagra Luzzatto, 2001.

22. FILHO, F. Coutinho. Violas e repentes: repentes populares, em prosa e verso. Pesquisas folclóricas no nordeste brasileiro. Recife, 1953.

23. FONSECA, Edson Nery da. O rosto gordo de Olinda e o perfil magro do Recife. Suplemento Cultural, Diário Oficial-PE, X: p. 12-13, março de 1996.

24. FREYRE, Gilberto. Guia prático, histórico e sentimental do Recife. Rio de Janeiro: José Olimpo, 1942 . 
25. FREYRE, Gilberto. Terra, homem e desenvolvimento: alguns aspectos brasileiros de uma inter-relação complexa. Revista Pernambucana de Desenvolvimento. Recife, 4 (2): 159-176, jul./dez, 1977.

26. FURTADO, Celso. A formação econômica do Brasil. São Paulo: Editora Nacional, 1974.

27. GIRONCOURT, Georges de. Un nouveau départament à la géographie: la géographie musicale. La Géographie. nsº 5-6, Paris: Société de Géographie, 1927. Pp. 292-302.

28. GOMES, Cilene. Telecomunicações, informática e informação e a remodelação do território brasileiro In SANTOS, Milton e SILVEIRA, María Laura. O Brasil: território e sociedade no início do século XXI. Rio de Janeiro: Record, 2005. Pp 345-356.

29. GOMES, Edvânia Tôrres Aguiar. Recortes da paisagem na cidade do Recife: uma abordagem geográfica. Recife: Fundaj-Massangana, 2007.

30. GOMES, Isaltina, TROTTA, Felipe \& LUSVARGHI, Luiza. Fora do eixo: indústria da música e mercado audiovisual no nordeste. Recife: Ed. UFPE, 210.

31. HARTSHORNE, Richard. Propósitos e natureza da geografia. São Paulo, Hucitec, 1978.

32. ISNARD, Hildebert. O espaço do geógrafo In: Boletim Geográfico. Rio de Janeiro. Nº. 258/259, jan./dez. 1978, Pp.05-17.

33. ISNARD, Hildebert. O espaço geográfico. Coimbra, Almedina, 1982.

34. LENCIONI, Sandra. Observações sobre o conceito de cidade e urbano. Revista Geousp. São Paulo, n² 24, pp. 109-123, 2008

35. LIMA, Ivaldo Marciano de França \& GUILLEN, Isabel Cristina Martins. Cultura afro-descendente no Recife: maracatus, valentes e catimbós. Recife: Bagaço, 2007. 250 p.

36. LIMA, Ivaldo Marciano de França. Identidade negra no Recife: maracatus e afoxés. Recife: Bagaço, 2009. 449

37. MACIEL, Jarbas. Um fenômeno chamado Spok. Continente Multicultural. V (56): 14-17, agosto 2005.

38. MARTIGNONI, Andrea. Objets et paysages sonores. Geógraphie et Cultures, n 59, 2006. (pp. 127-133).

39. MELO, Mário Lacerda de. Estratégia espacial para o nordeste. Revista Pernambucana de Desenvolvimento. Recife, 15 (1-2): 1-28, jul. /dez. 1974.

40. MELO, Mário Lacerda de. Metropolização e subdesenvolvimento: o caso do Recife. Recife: UFPE, 1978. 450

41. MIRANDA, Lívia Izabel Bezerra de. Organização socioespacial e mobilidade residencial na Região Metropolitana do Recife, PE. Cadernos Metrópole, n. 12, 2º sem. 2004. Pp. 123-144.

42. MONBEIG, Pierre. Pioneiros e fazendeiros de São Paulo. São Paulo: Hucitec, 1984 [1950].

43. MORAIS, Maria Luiza Nóbrega, LIMA, André Luiz de \& MARQUES, Bárbara. Anotações para a história do rádio em Pernambuco. Texto Apresentado no II Encontro Nacional da Rede Alfredo de Carvalho. Florianópolis, de 15 a 17 de abril de 2004. 21 pp. 
44. MOREIRA, Ruy. Da Região à rede e a lugar: a nova realidade e o novo olhar geográfico sobre o mundo. ETC: Espaço, tempo e crítica, vol. 1, n 1(3), 2007. Pp. 55-70.

45. MOTA, Sophia Karla Almeida. Frevo e identidade sociocultural pernambucana: um estudo etnoterminológico. Mestrado, Letras, Universidade Federal de Pernambuco. Recife, 2001.

46. MOURA, Alexandrina Sobreira de. Terra do mangue: invasões urbanas no Recife. Recife: Massangana, 1990.

47. NÓBREGA, Maria de Lourdes Carneiro da Cunha. Um estudo sobre as formas de apropriação do espaço público pelos comerciantes de rua na cidade do Recife. Mestrado, Desenvolvimento Urbano, Universidade Estadual de Pernambuco. Recife, 2002.

48. OLIVEIRA, Sheila Borges. O rádio na Região Metropolitana do Recife: do jornalismo à evangelização. Texto apresentado ao XXXIV Congresso Brasileiro de Ciências da Comunicação Recife, PE - 2 a 6 de setembro de 2011. 14 pp.

49. PAIVA, Carla Souza de. Os centros e a produção de novas centralidades urbanas: o caso do Shopping Center Recife. Mestrado, Desenvolvimento Urbano, Universidade Estadual de Pernambuco. Recife, 1996.

50. PHAELANTE, Renato. Pernambuco na discografia da MPB In o Som da Gota Serena. Suplemento Cultural, Diário Oficial-PE, p. 42-46, janeiro-fevereiro de 1998.

51. PONTUAL, Virgínia. O urbanismo no Recife: entre idéias e representações. Revista Brasileira de Estudos Urbanos e Regionais nº 2: 89-110. Nov. 1999.

52. PONTUAL, Virgínia. Experiências urbanísticas e representações de cidade: o Recife civilizado. (26-46 p.) In PONTUAL, Virgínia \& CARNEIRO, Ana Rita Sá (orgs). História e paisagem: ensaios Urbanísticos do Recife e de São Luís. Recife: Bagaço, 2005.

53. PRED, Alan. Sistemas de cidades: economia adiantada, crescimento passado, processos presentes e opções de desenvolvimento futuro. Rio de Janeiro: Zahar, 1979.

54. RATIS, Conceição. Essa é a cara de Pernambuco... (Será?) e a cara do Brasil! Suplemento Cultural, Diário Oficial-PE, p. 3-6, junho de 2004.

55. REYNALDO, Amélia (Org). Metrópole estratégica - Região Metropolitana do Recife. Recife: Agência Estadual de Planejamento e Pesquisas de Pernambuco, CONDEPE/FIDEM, Prómetrópole, 2005.

56. RIBEIRO, Ana Clara Torres. Mutações na sociedade brasileira: seletividade em atualizações técnicas da cultura. In SANTOS, Milton; SOUZA, Maria Adélia; SCARLATO, Francisco Capuano \& ARROYO, Monica. O Novo mapa do mundo. São Paulo: Hucitec, 1994. Pp. 151-170. 453

57. RIBEIRO, Ana Clara Torres. Por uma sociologia do presente: ação, técnica e espaço. Rio de Janeiro: Letra Capital, 2012.

58. SALDANHA, Leonardo; CARRASCO, Claudiney. O advento da música popular urbana do Recife no rádio e os seus desdobramentos na PRA-8. In: Congresso da Associação Nacional de Pesquisa e Pós-Graduação em Música, 2006. 16 pp.

59. SALGADO, Álvaro. Radiodifusão fator social. Revista Cultura Política. Rio de Janeiro, 1941. 
Pp. 79-93.

60. SANGUINETT, Maria Luiza. A música no Brasil e em Pernambuco: formação e tendências. Ciência e Trópico. Recife, 12 (2): 215-224, jul./dez., 1984.

61. SANTOS, Milton e SILVEIRA, María Laura. O Brasil: território e sociedade no início do século XXI. Rio de Janeiro: Record, 2001.

62. SANTOS, Milton. Técnica, espaço e tempo. São Paulo-SP: Hucitec, 1994 a.

63. SANTOS, Milton. A urbanização Brasileira. São Paulo-SP: Hucitec, 1994 b.

64. SANTOS, Milton. A natureza do espaço: técnica e tempo, razão e emoção. São Paulo: Hucitec, 1997.

65. SCHAFER. R. Murray. A afinação do mundo - uma exploração pioneira pela história passada e pelo atual estado do mais negligenciado aspecto do nosso ambiente: a paisagem sonora. São Paulo: Unesp, 1997 [1977].

66. SILVA, Leonardo Dantas. Pequena história do piano em Pernambuco In o Som da Gota Serena. Suplemento Cultural, Diário Oficial-PE, p. 3-10, janeiro-fevereiro de 1998.

67. SILVA, Leonardo Dantas. Nelson Ferreira: o maestro que não sabia compor. Continente Multicultural. II (13): 72-79, janeiro 2002.

68. SILVEIRA, María Laura. Uma situação geográfica: do método à metodologia. Revista Território, ano IV, no. 6, 1999. Pp. 21-27.

69. SILVEIRA, María Laura. Economia Política e ordem espacial: circuitos da economia urbana. In Território e ação social: sentidos da apropriação urbana. SILVA, Catia Antonia da. Rio de Janeiro: Faperj/Lamparina, 2011. Pp. 35-51.

70. SINGER, Paul. Desenvolvimento econômico e evolução urbana: análise de evolução econômica de São Paulo, Porto Alegre, Belo Horizonte e Recife. São Paulo: Editora Nacional da USP, 1968.

71. SOJA, Edward. O espaço como palavra-chave. In OLIVEIRA, Márcio Piñon de et all (Orgs). O Brasil, a América Latina e o mundo: espacialidades contemporâneas. Rio de Janeiro: Lamparina: Anpege, Faperj, 2008. Pp 17-51.

72. TELES, José. Do frevo ao manguebeat. Recife: Editora 34, 2000.

73. TELES, José. Quando o frevo imperava. Continente Multicultural. III (26): 42-47, fevereiro, 2003.

74. TELES, José. A música em Pernambuco. Recife: Editora A. L. do Estado de Pernambuco, 2004.

75. TINHORÃO, José Ramos. Música popular: do gramofone ao rádio e TV. São Paulo: Ática, 1981.

76. VICENTE, Eduardo. A música popular e as novas tecnologias de produção musicais: uma análise do impacto das tecnologias digitais no campo da produção da canção popular de massas. Dissertação de mestrado, Departamento Sociologia do Instituto de Filosofia e Ciências Humanas da Universidade Estadual de Campinas. Campinas, 1996.

Artigo recebido em 27 de março de 2015.

Artigo aceito em 10 de julho de 2015. 